\title{
Enterprise Architecture Planning for Balikpapan Environmental Services Using TOGAF ADM
}

\author{
Lovinta Happy ATRINAWATI ${ }^{1 *}$, Muhammad Aqil MAULANA ${ }^{2}$, Tegar Palyus \\ FIQAR $^{3}$, and Soleh ARDIANSYAH ${ }^{4}$
}

\begin{abstract}
1,2,3,4 Department Of Information System, Kalimantan Institute Of Technology, Balikpapan, Indonesia *Corresponding Author: lovinta@lecturer.itk.ac.id
\end{abstract}

\begin{abstract}
Implementation of Enterprise Architecture (EA) is an integral part to ensure IT investments deliver values aligned with business strategy. The Balikpapan Environmental Services (Dinas Lingkungan Hidup - DLH) main task is compiling and implementing government affairs in terms of environmental field. Although DLH of Balikpapan already implementing IT to support and enhance the value of its business processes, there is a very limited alignment between business strategy and IT. TOGAF ADM framework is used to develop DLH's Enterprise Architecture. Based on the EA, there are 5 information systems that needs to be developed for maximum value and service by the DLH, specifically the Financial Information system, the Environmental Public Service Management System, and the Administrative Management System.

Keywords: Architecture, TOGAF, information
\end{abstract}

\section{INTRODUCTION}

Organizations are starting to design digital value creation concepts. However, these means are very limited when it comes to deriving and implementing processes and IT services. In contrast to existing IT-based products, the new service logic requires a holistic process view. To optimize the value of the IT, methods and tools are needed. Enterprise architectures (EA) offers a well-proven solution for this challenge [1]. Implementation of EA is an integral part to ensure IT investments deliver values aligned with business strategy [2].

The Balikpapan Environmental Services (Dinas Lingkungan Hidup - DLH) is an instituttion formed from the merger of two regional institutions, the Environmental Agency (Badan Lingkungan Hidup - BLH) and the Parks and Cemeteries Cleanliness Services (Dinas Kebersihan Pertamanan dan Pemakaman - DKPP). The DLH's main task is compiling and implementing government affairs in terms of environmental field [3]. Currently, the DLH of Balikpapan has 2 applications to support its business process, which are the website of DLH of Balikpapan and website of Balikpapan Botanical Garden. Although DLH of Balikpapan already implementing IT to support and enhance the value of its business processes, there is a very limited alignment between business strategy and IT. To maximize value creation of IT implementation, DLH needs to implement EA. This research aims to develop enterprise architecture for the Balikpapan Environmental Services using TOGAF ADM framework.

\section{LITERATURE REVIEW}

\section{Enterprise Architecture}

Enterprise Architecture (EA) is an approach for managing the complexity of an organization's structures, business environments, amd different information system, and for facilitating integration of strategy, personel, business, data, and IT [6]. EA also defines the current and desirable states of an organization's process, capabilities, application system, data, and IT infrastructure and provides a roadmap for achieving this target from the current state [7]. The right EA approach can help organizations to become more successful in their IT investments[8].Implementation of EA Service Capability and EA Governance has positive impact in IT-driven and business driven dynamic capabilities that lead to positive impact in project benefits. This lead to strong positive impact of Organizational benefits [2]. Some research on the EA implementation in government services has brought benefits for the institution. The first research on the implementation of EA in the Field of Conservation and Climate Change Control on Dinas Lingkungan Hidup (DLH) of West Java Province using TOGAF ADM and the second research about Optimizing Information Technology With Modeling Enterprise Architecture Areas Of Environment Polling Control Using TOGAF ADM On Dinas Lingkungan Hidup. 
West Java Province. Both researches show that implementation of EA using TOGAF ADM can create an architectural blueprint that shows current and desirable state in business architecture, information architecture, and technology architecture that can be integrated into the IT Development Roadmap of the organization [4] [5].

\section{The Open Group Architecture Framework (TOGAF)}

TOGAF is an architecture framework that developed and maintained by The Open Group Architecture Forum. The first version of TOGAF, developed in 1995, was based on the US Department of Defense Technical Architecture Framework for Information Management (TAFIM) [9]. TOGAF provide guideliness and methodology to develope architecture namely Architecture Development Method (ADM)

The ADM describes the ten different phase of EA development as a Generic Method. Its cycles start with Preliminary phase which prepares and initializes the EA management approach. After the preparation and initialization activities are performed, the scope of the EA management endeavor is defined within the Architecture Vision phase. Then based on the architecture vision, Business Architecture, Information System Architecture, and Technology Architecture are developed. After that gap analysis is performed to evaluate the difference between the current and target architecture. In the final phase namely Opportunities and Solutions, the transformation from the current to the target architecture are described [10]

\section{RESULTS AND DISCUSSION}

\section{Architecture Vision}

This section explains about organization's goals which consist of vision and mission statement. It's very important to write vision and mission statement. These purpose are to ensure alignment between business architecture, application architecture, and technology architecture with organization's goals. The DLH's vision is "The realization of a sustainable balance of economic and environmental development in the frame of "madinatul iman", while the mission are

- Enhancing stakeholder partnerships in improving the quality of participatory environmental management.

- Realizing the preservation of natural resources, biodiversity and prevention of pollution of the environment.

- Improve environmental impact control, supervision and enforcement of environmental law.

- Developing institutions and the quality of professional apparatuses in environmental management.

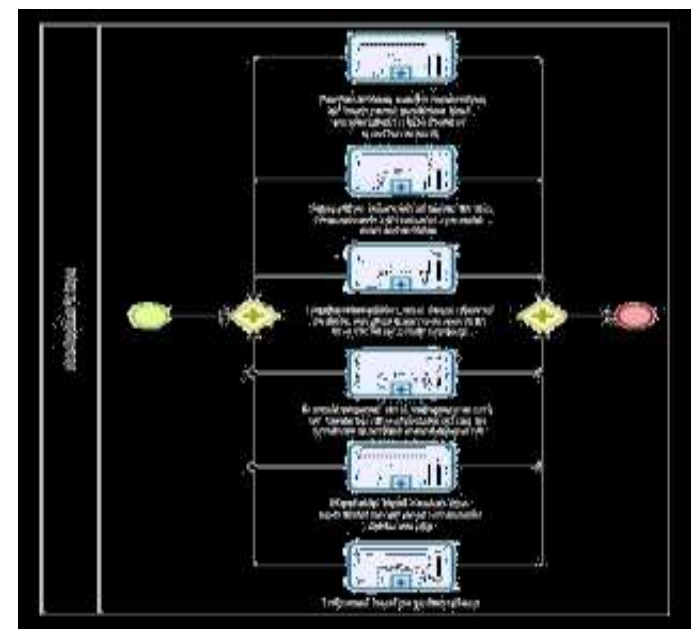

Figure 1 Main Bussiness Function

\section{Business Architecture}

Briefly, the general business functions carried out by the Balikpapan environmental office are formulating, arranging, monitoring, coordinating, fostering, improving and organizing the policies of the Balikpapan City Environmental Agency. The organization's core business function can be seen in figure 1

Department of environment of Balikpapan has 6 core business function which consists of public service business function and internal business function. For the public service business function, this organization responsible for formulation and preparation of technical policies and strategies in the field of environment, supervise and coordinate in the framework of natural resource conservation, development and enhancement of community participation, non-governmental and private institutions in environmental management, implementation and organizer of public service improvement in the field of environment, evaluate and assess the application of environmental documents. The internal business functions are formulating government agency performance reports and formulating strategic plans.

The business function of the formulation and preparation of technical policies and strategies in the environmental field consists of several business processes. These are the issuance of the permit for groundwater drilling company (SIPPAT), terms of reference assessment, formulate data information policy, issuance of the permit for disposal of wastewater, the procedure for waste management with sanitary final disposal sites, issuance of the permit for the use of Balikpapan botanical gardens. The business function of supervising and coordinate in the framework of natural resource conservation consists of several business processes. These are the issuance of tree cutting permits and tree pruning cutting recommendations, environmental management field monitoring. The business function of development and enhancement of community participation, non-governmental and private institutions in environmental management consists of several business processes. These are cleaning service/waste retribution, B3 waste management for B3 
waste storage activities, and management of complaints on environmental disputes. The business function of Implementation and Organizer of Public Service Improvement in the Field of Environment consist of several business processes. These are Procurement of Tree Seed Aid, Management of Transporting Garbage from a temporary disposal site to a landfill, Road and Environmental Cleaning Services, Construction of solid waste facilities and infrastructure. The business function to evaluate and assess the application of environmental documents consists of several business processes. These are the analysis of environmental impacts (AMDAL), environmental management plans (RKL), Environmental Monitoring Plans (RPL), Environmental Management Efforts (UKL), and Environmental Monitoring Efforts (UPL).

These functions are assigned to a division. Although, the division may not perform all the business process in that business function. Some business processes are performed as a collaboration between more than one divisions. There are also business processes carried out by division outside of their business functions. There are six divisions in the Department of Environment of Balikpapan. These are Secretariat that carried out the function of evaluating and assessing the application of environmental documents, Sub Division of Finance that carried out function formulating RENSTRA and LKJIP. Sub Division of General that handle the business process of insurance permit for the use of Balikpapan Botanical Garden, Division of Environmental Management and Protection of Natural Resources, Division of Sanitation and Cleanliness, Division of Pollution Control and Environmental Damage, Division of Legal Arrangement and Environmental Capacity Enhancement.

\section{Information Architecture}

This section explains about data architecture and applications that organizations use to optimize it business function/process value.

\section{Data Architecture}

Data architecture defines the data entity used by business process/function. The relationship between data entity and business function/process (represented by division) in Balikpapan Environmental Services can be seen in table 1 
Table 1 Data Architecture

\begin{tabular}{|c|c|}
\hline $\begin{array}{l}\text { Business } \\
\text { Function }\end{array}$ & Data Entity \\
\hline \multirow{14}{*}{ Division of } & Draft Statement \\
\hline & File and Completeness of SPPL \\
\hline & SPPL Registration Letter \\
\hline & File Complete Terms of Reference \\
\hline & Final Reference Framework Repair Documents \\
\hline & Draft Recommended Terms of Reference \\
\hline & Application File AMDAL -RKL \& RPL \\
\hline & \\
\hline & File for Improvement of AMDAL-RKL \& RPL \\
\hline & Final Document File AMDAL-RKL \& RPL \\
\hline & Application for UKP-UPL \\
\hline & UKL-UPL file \\
\hline & File for UKL-UPL Improvement \\
\hline & UKL-UPL News Document \\
\hline
\end{tabular}

\begin{tabular}{|l|l|}
\multirow{5}{*}{ Division of } & Draft SK Tim Penyusunan RENSTRA Dinas \\
\cline { 2 - 2 } Finance & Draft RENSTRA Dinas \\
\cline { 2 - 2 } & Draft Final RENSTRA \\
\cline { 2 - 2 } & Draft Agenda Penyusunan LKJIP \\
\cline { 2 - 2 } & Nota Dinas LKJIP \\
\cline { 2 - 2 } &
\end{tabular}









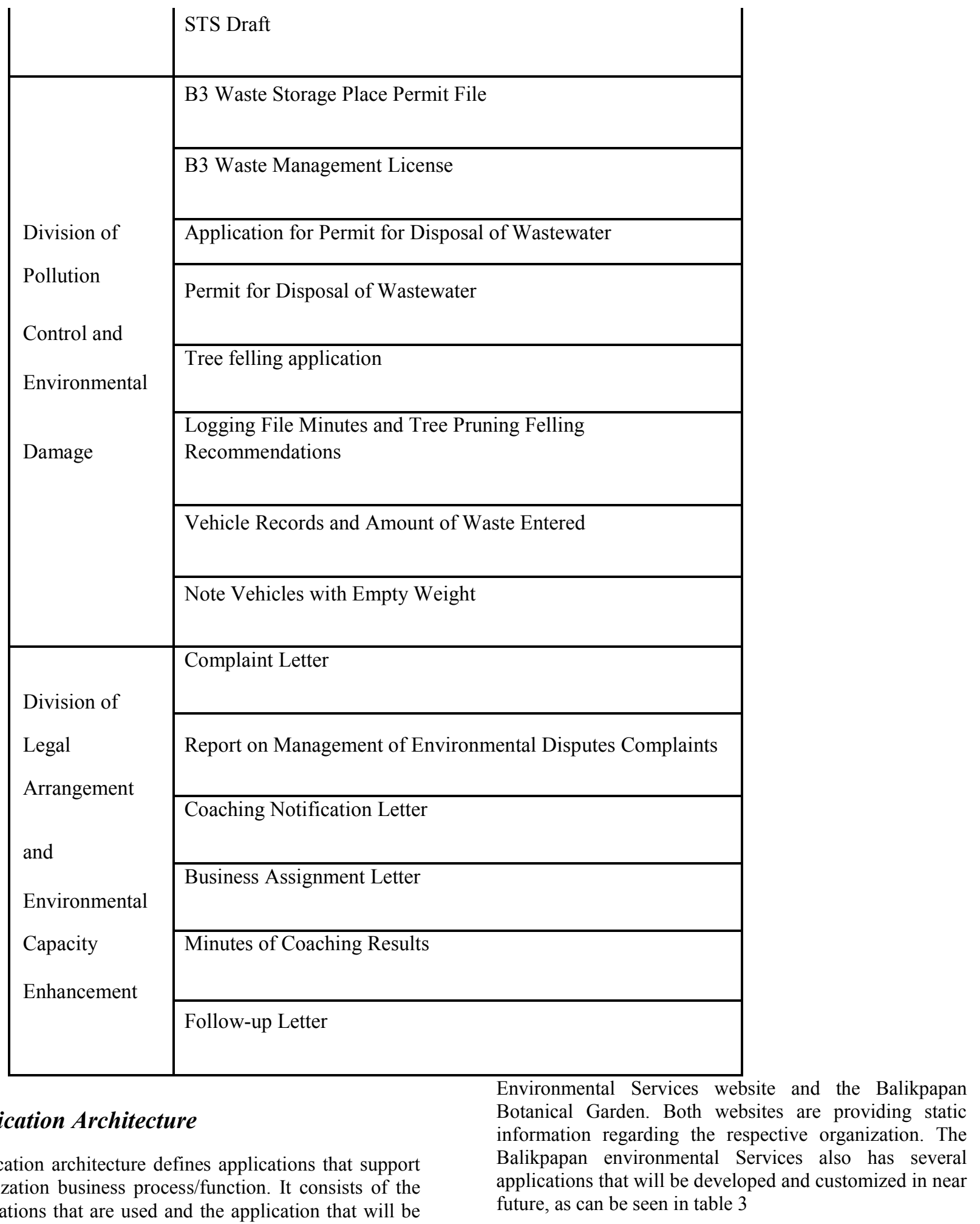
applications that are used and the application that will be implemented/developed by the organization. The existing applications used by the DLH are Balikpapan 
Table 2 Application to be developed and customized

\begin{tabular}{|c|c|}
\hline Information System Candidate & Description \\
\hline Administration Management System & $\begin{array}{l}\text { An Application that simplifies bureaucratic processes and } \\
\text { administration of internal documents. }\end{array}$ \\
\hline $\begin{array}{l}\text { Balikpapan Botanical Gardens } \\
\text { Management Information System }\end{array}$ & $\begin{array}{l}\text { An application that facilitates the licensing process using the } \\
\text { Balikpapan botanical garden. This application speeds up the licensing } \\
\text { administration process and allows applicants to make requests } \\
\text { online. applicants can also see the status of the application and see the } \\
\text { usage schedule }\end{array}$ \\
\hline $\begin{array}{l}\text { Environmental Public Service } \\
\text { Management System }\end{array}$ & $\begin{array}{l}\text { An application that provides an easy application for AMDAL, UKL, } \\
\text { UPL, RPL, RKL, SIPPAT, environmental dispute complain, and } \\
\text { other environmental administration documents. }\end{array}$ \\
\hline Road \& Waste Management System & $\begin{array}{l}\text { An application that handles the business of waste and road } \\
\text { management processes such as sweeping the road, planting and } \\
\text { pruning trees on the roadside, monitoring the capacity of temporary } \\
\text { dumps, monitoring the amount of waste entering, managing } \\
\text { hazardous waste and wastewater }\end{array}$ \\
\hline Financial Information System & Managing funds and expenditure following government regulations \\
\hline
\end{tabular}

\section{Technology Architecture}

The technology architecture describes a technological infrastructure consisting of software and hardware that supports the operations of the organization's information architecture.

\section{Hardware Configuration}

Below the existing hardware infrastructure that is used by Balikpapan Environmental Services. 
Table 3 Hardware Configuration

\begin{tabular}{|l|l|}
\hline \multicolumn{1}{|c|}{ Hardware } & \multicolumn{1}{|c|}{ Specification } \\
\hline Server and PC & $\begin{array}{l}\text { ASUS Desktop PC K31 AD-ID008T (18.5 Inch, Core i3, 2 } \\
\text { GB, 500 GB, Win 10) }\end{array}$ \\
\hline PC (Laptop) & $\begin{array}{l}\text { Laptop Asus X441MA-GA011T N4000 RAM 4GB HDD } \\
500 G B\end{array}$ \\
\hline Switch & $\begin{array}{l}\text { SRW224G4-K9-EU Cisco Small Business Managed } \\
\text { Switch 24 Ports }\end{array}$ \\
\hline Router & CISCO Wireless N VPN Router CVR100W \\
& LINKSYS Wireless-G Router [WRT54GL-AS] \\
\hline Access Point & TP-LINK 300Mbps Wireless N Outdoor Access Point \\
\hline
\end{tabular}

\section{Software Configuration}

Below the existing software infrastructure that is used by Balikpapan Environmental Services.

Table 4 Software Configuration

\begin{tabular}{|l|l|}
\hline \multicolumn{1}{|c|}{ Software } & \multicolumn{1}{c|}{ Specification } \\
\hline Webserver & Apache \\
& MySQL \\
\hline DBMS & MySQL, Oracle \\
\hline Operating System & \\
\hline
\end{tabular}


an access point on the 3rd floor. Each router is connected to personal computers and laptops through a wireless connection. The connection between the router and the devices made using coaxial cable network and wireless connection. The description of the network used by

Department of Environment of Balikpapan implemented a tree topology in its network design. There were 3 floors with 1 router on each floor. All of them are connected through a network cable and form local area Department of Environment of Balikpapan can be seen in figure 2

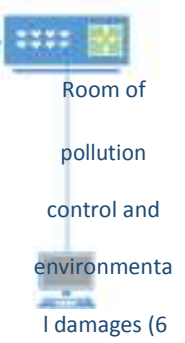

PC)

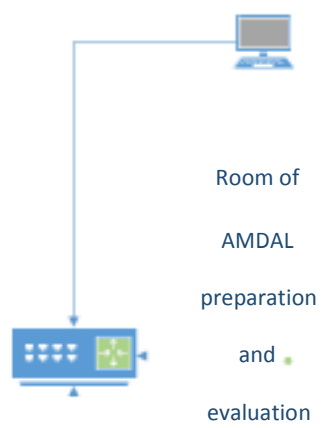

(6 PC)



Figure 2 Network Configuration 


\section{Opportunities And Solution}

This section provides opportunities and solution based on proposed information systems in the form of development priority and the scope of the information system that would be developed

\section{Development Priority}

There are 5 main factors that determine development priorities. These factors are the impact on customers or external entities, the impact on the quality of services or products, the reduction in business costs, the impact on internal customers, and the impact of process speed. Each criterion is then ranked based on the importance of the performance impact for the company using a 7-10 scale. Then each criterion is assigned to the project using a scale of0-10. After that, each criterion scale is multiplied by the project score and then the results are added. The sum results are then arranged based on the value. The greatest value refers to the highest development priority and the smallest value refers to the lowest development priority. [11]Score And Then The Results Are Added. The Sum Results Are Then Arranged Based On The Value. The Greatest Value Refers To The Highest Development Priority And The Smallest Value Refers To The Lowest Development Priority. [11]

\section{Develop Weighting Criteria}

The weight of criteria are showed in the table below

Table 5 Weighting Criteria

\begin{tabular}{|l|l|r|}
\hline No & Performance Criteria & Weight \\
\hline 1 & External Customers & 10 \\
\hline 2 & Quality of the service & 7 \\
\hline 3 & Reduction of business costs & 7 \\
\hline 4 & Impact on on internal customers & 9 \\
\hline 5 & Impact of the speed of the process & 8 \\
\hline
\end{tabular}

Priority Of Information System Development

The information system developement developement priority can be seen in the table below. 
Table 6 Priority Of Information System Developement

\begin{tabular}{|c|c|c|c|c|c|c|c|}
\hline & $\begin{array}{l}\text { Multiplier } \\
\text { Weight }\end{array}$ & 10 & 7 & 7 & 9 & 8 & \\
\hline No & $\begin{array}{l}\text { Information } \\
\text { System Name }\end{array}$ & $\begin{array}{l}\text { External } \\
\text { Customers }\end{array}$ & $\begin{array}{l}\text { Quality } \\
\text { of the } \\
\text { service }\end{array}$ & $\begin{array}{l}\text { Reduction } \\
\text { Of } \\
\text { bussiness } \\
\text { costs }\end{array}$ & $\begin{array}{l}\text { Impact on } \\
\text { on internal } \\
\text { customers }\end{array}$ & $\begin{array}{l}\text { Impact of } \\
\text { the speed } \\
\text { of the } \\
\text { process }\end{array}$ & $\begin{array}{l}\text { Total } \\
\text { Value }\end{array}$ \\
\hline 1 & $\begin{array}{l}\text { Financial } \\
\text { Information } \\
\text { System }\end{array}$ & 10 & 9 & 7 & 10 & 6 & 350 \\
\hline 2 & $\begin{array}{l}\text { Environmental } \\
\text { Public Service } \\
\text { Management } \\
\text { System }\end{array}$ & 10 & 9 & 5 & 9 & 7 & 335 \\
\hline 3 & $\begin{array}{l}\text { Administration } \\
\text { Management } \\
\text { System }\end{array}$ & 5 & 5 & 8 & 10 & 10 & 311 \\
\hline 4 & $\begin{array}{l}\text { Balikpapan } \\
\text { Botanical } \\
\text { Gardens } \\
\text { Management } \\
\text { Information } \\
\text { System }\end{array}$ & 9 & 8 & 5 & 5 & 7 & 282 \\
\hline 5 & $\begin{array}{l}\text { Road \& Waste } \\
\text { Management } \\
\text { System }\end{array}$ & 5 & 8 & 5 & 7 & 5 & 244 \\
\hline
\end{tabular}

Scope Of Information System Development

In the scope of information system development is made to determine the features and who are the users involved in the use of operational information systems. 
Table 7 Scope Of Information System Development

\begin{tabular}{|c|c|c|c|}
\hline No & $\begin{array}{l}\text { Information } \\
\text { System Candidate }\end{array}$ & Functional Requirement & User \\
\hline 1 & $\begin{array}{l}\text { Financial } \\
\text { Information } \\
\text { System }\end{array}$ & Manage financial reports & $\begin{array}{l}\text { Division of } \\
\text { Finance }\end{array}$ \\
\hline 2 & $\begin{array}{l}\text { Environmental } \\
\text { Public Service } \\
\text { Management } \\
\text { System }\end{array}$ & $\begin{array}{l}\text { Provide interface for proposing } \\
\text { environmental related document } \\
\text { Provide guideliness for proposing } \\
\text { environmental related document } \\
\text { Provide environmental document archieve } \\
\text { for public } \\
\text { Provide interface for environmental dispute } \\
\text { Complain }\end{array}$ & $\begin{array}{l}\text { Divison of } \\
\text { Secretariat, } \\
\text { Division of } \\
\text { TLPSDA, } \\
\text { Division of Legal } \\
\text { Arrangement and } \\
\text { Environmental } \\
\text { Capacity } \\
\text { Enhancement, } \\
\text { Public }\end{array}$ \\
\hline 3 & $\begin{array}{l}\text { Administration } \\
\text { Management } \\
\text { System }\end{array}$ & $\begin{array}{l}\text { Manage Report } \\
\text { Archiving documents } \\
\text { Track and Monitor Organization Goals }\end{array}$ & All Division \\
\hline 4 & $\begin{array}{l}\text { Balikpapan } \\
\text { Botanical Gardens } \\
\text { Management } \\
\text { Information } \\
\text { System }\end{array}$ & $\begin{array}{l}\text { Provide interface for permit usage license } \\
\text { of Balikpapan Botanical Garden } \\
\text { Provide bussy calendar } \\
\text { Provide usage history } \\
\text { Provide visitor counter }\end{array}$ & 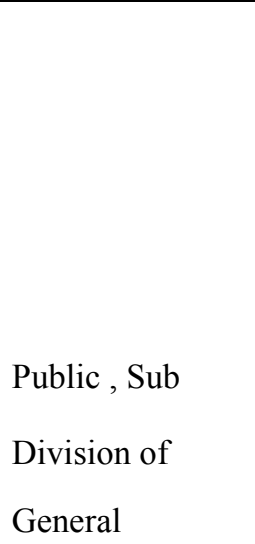 \\
\hline 5 & & $\begin{array}{l}\text { Managing daily schedule for sweeping } \\
\text { Roads } \\
\text { Mapping tree location on the roadside and }\end{array}$ & \\
\hline
\end{tabular}




\begin{tabular}{|c|c|c|}
\hline $\begin{array}{l}\text { Road \& Waste } \\
\text { Management } \\
\text { System }\end{array}$ & $\begin{array}{l}\text { it age } \\
\text { monitoring the capacity of temporary } \\
\text { dumps in real-time } \\
\text { monitoring the amount of waste entering in } \\
\text { real-time } \\
\text { managing hazardous waste and wastewater } \\
\text { in real-time }\end{array}$ & $\begin{array}{l}\text { Division of } \\
\text { Sanitation and } \\
\text { Cleanliness, } \\
\text { Division of } \\
\text { Pollution Control } \\
\text { and } \\
\text { Environmental } \\
\text { Damage }\end{array}$ \\
\hline
\end{tabular}

\section{CONCLUSION}

Based on the enterprise architecture, there are several opportunities to improve existing business processes. Opportunities are translated in the form of information systems as contained in the design of information systems architecture. There are 5 information systems that can be developed. Information system priorities are then arranged based on 5 criteria namely external customer impact, service quality, business cost reduction, internal customer impact, and process speed impact. Information systems that are highly prioritized for development are the Financial Information system, the Environmental Public Service Management System, and the Administrative Management System. Information systems that are not prioritized to be developed are the Balikpapan Botanical Garden Management Information System and the Road \& Waste Management System.

\section{ACKNOWLEDGMENT}

Authors would like to express gratitude for research funding granted by Ministry of Research and Higher Education 2019 so that this research can be conducted. Authors also would like to thank Balikpapan Environmental Services for collaborating during this research.

\section{REFERENCES}

[1] D. Goerzig Und T. Bauernhansl, ,Enterprise Architectures For The Digital Transformation In

[2] Small And Medium-Sized Enterprises, “ In 11th Cirp Conference On Intelligent Computation In Manufacturing Engineering, 2017.

[3] M. Gloet, K. Frampton Und I. A. Someh, „Achieving Benefits With Enterprise Architecture,“

[4] Journal Of Strategic Information Systems, Nr. 27, P. 139-156, 2018.

[5] Dinas Lingkungan Hidup Balikpapan, „Gambaran Umum,“ 18 Agustus 2019. [Online].

[6] Available: Http://DLH.Balikpapan.Go.Id/Content/19/Ga mbaran-Umum.
A. Maulana, I. Darmawan Und P. F. Alam, „Optimizations Information Technology With

[7] Enterprise Using TOGAF ADM On Conservation Field And Control Of Climate Change Dinas

[8] Lingkungan Hidup West Java Control Of Climate Change Dinas Lingkungan Hidup West Java,“

[9] E-Proceeding Of Engineering, Bd. 5, Nr. 3, P. 7142, 2018. 
[10] S. N. Ayudya, I. Darmawan Und P. F. Alam, „Optimizing Information Technology With

[11] Modeling Enterprise Architecture Areas Of Environment Polling Control Using TOGAF ADM On Dinas Lingkungan Hidup West Java Province," E-Proceeding Of Engineering, Bd. 5, Nr. 3, P. 7262, 2018.

[12] Dinh Duong Dang; Samuli Pekkola, ,Systematic Literature Review On Enterprise Architecture In The, “ The Electronic Journal Of E-Government, Bd. 15, Nr. 2, Pp. 132-154, 2017.

[13] T. Tamm, P. Seddon, G. Shanks Und P. Reynolds, „How Does Enterprise Architecture Add Value To Organisations?,“ Communications Of The Association For Information Systems., Bd. 28, Pp. 141-168, 2011.

[14] L. Halawi, R. Mccarthy Und J. Farah, „Where We Are With Enterprise Architecture," Journal Of Information Systems Applied Research, Bd. 12, Nr. 3, Pp. 4-13, 2019.

A. Josey, R. Harrison, P. Homan, M. F. Rouse, T. V. Sante, M. Turner Und P. V. D. Merwe, TOGAF® Version 9.1 - A Pocket Guide, Zaltbommel: Van Haren Publishing, 2016.

[15] S. Buckl, A. M. Ernst, F. M. R. Ramacher Und C. M. S. , „Using Enterprise Architecture

[16] Management Patterns To Complement TOGAF, “In Ieee International Enterprise Distributed Object Computing Conference, 2009.

A. Cassidy, A Practical Guide To Information System Strategic Planning, Boca Raton, Florida: Auerbach Publications, 2006. 